\title{
Transport of Cytoplasmically Synthesized Proteins into the Mitochondria in a Cell Free System from Neurospora crassa
}

\author{
Matthew A. HARMEY, Gerhard HALLERMAYER, Harald KORB, and Walter NEUPERT \\ Institut für Physiologische Chemie, Physikalische Biochemie und Zellbiologie der Universität München \\ (Received July 11, 1977)
}

Synthesis and transport of mitochondrial proteins were followed in a cell-free homogenate of Neurospora crassa in which mitochondrial translation was inhibited. Proteins synthesized on cytoplasmic ribosomes are transferred into the mitochondrial fraction. The relative amounts of proteins which are transferred in vitro are comparable to those transferred in whole cells.

Cycloheximide and puromycin inhibit the synthesis of mitochondrial proteins but not their transfer into mitochondria.

The transfer of immunoprecipitable mitochondrial proteins was demonstrated for matrix proteins, carboxyatractyloside-binding protein and cytochrome $c$.

Import of proteins into mitochondria exhibits a degree of specificity. The transport mechanism differentiates between newly synthesized proteins and preexistent mitochondrial proteins, at least in the case of matrix proteins.

In the cell-free homogenate membrane-bound ribosomes are more active in the synthesis of mitochondrial proteins than are free ribosomes. The finished translation products appear to be released from the membrane-bound ribosomes into the cytosol rather than into the membrane vesicles.

The results suggest that the transport of cytoplasmically synthesized mitochondrial proteins is essentially independent of cytoplasmic translation; that cytoplasmically synthesized mitochondrial proteins exist in an extramitochondrial pool prior to import; that the site of this pool is the cytosol for at least some of the mitochondrial proteins; and that the precursors in the extramitochondrial pool differ in structure or conformation from the functional proteins in the mitochondria.

In the preceding paper we studied the transport of cytoplasmically synthesized proteins into the mitochondria in intact cells of Neurospora crassa [1]. In whole cells, the processes of synthesis and transport are not easily separated. Furthermore, post-labelling fractionation artifacts may obscure the intracellular location of mitochondrial proteins which are on their path from the site of synthesis to the site of function.

In considering systems in vitro a number of possibilities exist, ranging from cell-free homogenates to reconstituted systems involving isolated and purified protein and organelle components. In the present study we have investigated synthesis and transport in a cell-free homogenate. We have employed this system in an attempt to decide between two mechanisms currently proposed for the transport of mitochondrial proteins. The first mechanism is based on observations with whole Neurospora cells [1]. This mechanism proposes the existence of extramitochondrial pools of mitochondrial proteins from which they are imported into the mitochondria. The second mechanism is that proposed by Butow and his colleagues $[3-6]$. This latter mechanism proposes a special class of cytoplasmic ribosomes which are attached to the mitochondria at specific sites. The nascent polypeptides from these ribosomes are discharged in a vectorial manner into the mitochondria.

The results we present here support our earlier proposal on the existence of extramitochondrial precursors of mitochondrial proteins $[1,2]$.

\section{MATERIALS AND METHODS}

Growth of Neurospora cells

Neurospora hyphae (wild type 74A) were grown at $25^{\circ} \mathrm{C}$ for $11-13 \mathrm{~h}$ in the presence of $\left[{ }^{35} \mathrm{~S}\right]$ sulfate [1]. A chase of unlabelled sulfate was added and cells were grown for a further $2 \mathrm{~h}$. For harvesting, the cultures were poured into two volumes of iced distilled water and the hyphae collected by filtration. 


\section{Preparation of Cell-Free Extract}

$1 \mathrm{~g}$ of hyphae (wet weight) was mixed in a sterile mortar with $2 \mathrm{~g}$ of sterile sand (Quartz sand, RiedelDeHaen, Hannover) and moistened with $1 \mathrm{ml}$ of incubation mixture. The incubation mixture contained $0.15 \mathrm{M}$ sucrose, $0.03 \mathrm{M} \mathrm{KCl}, 0.01 \mathrm{M} \mathrm{MgCl}_{2}, 0.002 \mathrm{M}$ EDTA, $0.02 \mathrm{M} \mathrm{KH} \mathrm{KH}_{2} \mathrm{PO}_{4}, 0.06 \mathrm{M}$ triethanolamine$\mathrm{HCl}, 0.03 \mathrm{M}$ triethanolamine, $0.00025 \mathrm{M}$ of all $\mathrm{L}$-form amino acids (except leucine), $0.002 \mathrm{M} \mathrm{ATP}, 0.0005 \mathrm{M}$ GTP. The pH was adjusted to 7.85 with $1 \mathrm{M} \mathrm{KOH}$. The hyphae were ground thoroughly for $5 \mathrm{~min}$, then another $1 \mathrm{ml}$ of incubation mixture was added and grinding was continued for $2 \mathrm{~min}$. All operations were carried out at $0-4{ }^{\circ} \mathrm{C}$. The resulting slurry was centrifuged twice by $5 \mathrm{~min}$ at $2000 \times \mathrm{g}$ (max.) in a Sorvall RC-5 refrigerated centrifuge. The supernatant was used as cell-free homogenate for studies on synthesis and transport of mitochondrial proteins.

\section{Conditions of Amino Acid Incorporation}

Chloramphenicol was added to a final concentration of $0.5 \mathrm{mg} / \mathrm{ml}$ by adding $25 \mu \mathrm{l}$ per $\mathrm{ml}$ of homogenate of a concentrated solution of D-chlorampheni$\mathrm{col}$ in ethanol/water $(1 / 1, \mathrm{v} / \mathrm{v})$. Chloramphenicol was a gift from Bayer (Leverkusen). $\left[{ }^{3} \mathrm{H}\right]$ Leucine (New England Nuclear Co., Boston) $(40-60 \mathrm{Ci} / \mathrm{mol}$ specific radioactivity) was added at a concentration of $0.25 \mathrm{Ci} / 1$ homogenate. $0.01 \mathrm{M}$ creatine phosphate and $0.05 \mathrm{mg}$ / $\mathrm{ml}$ creatine kinase (Sigma Chem. Co., St Louis, Mo.) were added as an ATP regenerating system. The homogenate was brought to $25^{\circ} \mathrm{C}$ and incubated at this temperature for the time periods indicated in the individual experiments. When indicated, cycloheximide and puromycin (Sigma Chem. Co., St Louis, Mo.) were added to the homogenate in final concentrations of $0.36 \mathrm{mM}$ and $0.5 \mathrm{mM}$, respectively.

Samples $(0.5 \mathrm{ml})$ were withdrawn from the incubation mixture by rapidly cooling them to $0{ }^{\circ} \mathrm{C}$ and cell fractions were isolated by differential centrifugation as described [1]. Incorporation of $\left[{ }^{3} \mathrm{H}\right]$ leucine into the protein of the homogenate, and of mitochondrial, microsomal, ribosomal and cytosolic fractions was measured after pipetting samples onto Whatman GFC filter discs presoaked in $10 \%$ trichloroacetic acid in ether. The discs were washed as described [1].

Dodecylsulfate gel electrophoresis and radioactivity measurements were performed as reported previously [1].

Preparation of antibodies and immunoprecipitations were carried out as described [1]. Antiserum against bovine serum albumin was prepared by four injections of $4 \mathrm{mg}$ bovine serum albumin (Behringwerke, Marburg) emulsified in Freund's complete adjuvant into a rabbit. Antiserum against cytosolic proteins of Neurospora were raised by injecting five times with $1 \mathrm{ml}$ of a cytosol fraction (protein concentration $5.7 \mathrm{mg} / \mathrm{ml}$ ) emulsified in Freund's complete adjuvant.

\section{RESULTS}

Incorporation of $\left[{ }^{3} \mathrm{H}\right]$ Leucine into the Proteins of Various Cell Fractions in a Cell-Free Homogenate

A cell-free extract was prepared from cells grown in the presence of $\left[{ }^{35} \mathrm{~S}\right]$ sulfate. Chloramphenicol at a concentration of $500 \mu \mathrm{g} / \mathrm{ml}$ was added to block mitochondrial translation. In separate experiments it was shown that chloramphenicol in fact completely inhibits the labelling of intramitochondrially synthesized proteins in our cell-free homogenates. $\left[{ }^{3} \mathrm{H}\right]$ Leucine was added and incorporation was allowed to proceed at $25{ }^{\circ} \mathrm{C} .{ }^{3} \mathrm{H}$ and ${ }^{35} \mathrm{~S}$ radioactivities were determined in the protein of the total homogenate and in the various subcellular fractions. The ${ }^{35} \mathrm{~S}$ radioactivity served as a reference for pre-existing proteins, whereas the ${ }^{3} \mathrm{H}$ label indicates the proteins synthesized in vitro.

Incorporation into the homogenate started immediately and reached a plateau within $10-15 \mathrm{~min}$ (Fig. 1A). Addition of cycloheximide at zero time completely inhibited incorporation. The ${ }^{3} \mathrm{H}$ radioactivity in the protein after 15 min varied from $7-$ $10 \times 10^{6}$ counts $\times \mathrm{min}^{-1} \times \mathrm{ml}^{-1}$ of incubation mixture (corresponding to $0.5 \mathrm{~g}$ of cells wet weight or a total of 10-20 mg protein). Such high levels of radioactivity were necessary to detect with accuracy the small amounts of individual proteins synthesized.

The individual cellular fractions showed characteristic labelling kinetics (see Fig. 1).

The appearance of the label in the mitochondria was slow with respect to the other fractions shown. However, the mitochondria continued to accumulate label over the full incorporation period, the final ${ }^{3} \mathrm{H} /{ }^{35} \mathrm{~S}$ ratio being quite close to that of the cytosol.

In Table 1 are set out the ${ }^{3} \mathrm{H}$ and ${ }^{35} \mathrm{~S}$ radioactivities among the various cell fractions. The microsome fraction recovered constitutes some $2 \%$ of the total cellular protein. This value does not reflect the true proportion of this fraction of the total homogenate. Considerable amounts of microsomal material are precipitated with the mitochondrial fraction and are lost in the successive wash procedures.

Quantitative studies on the recovery of ${ }^{35} \mathrm{~S}$ radioactivity in the homogenates indicated that the microsomal fraction constitutes some $5-10 \%$ of the total protein of the homogenate. Ribosomes constitute some $20-30 \%$ of the total protein while the cytosol contains some $60 \%$. The mitochondrial fraction constitutes about $10 \%$ of the total protein of the homogenate. The isolation procedures used to obtain mitochondria involve substantial losses of mitochondrial material. This estimate, therefore, errs on the low side. From cytochrome $a a_{3}$ determinations in whole 


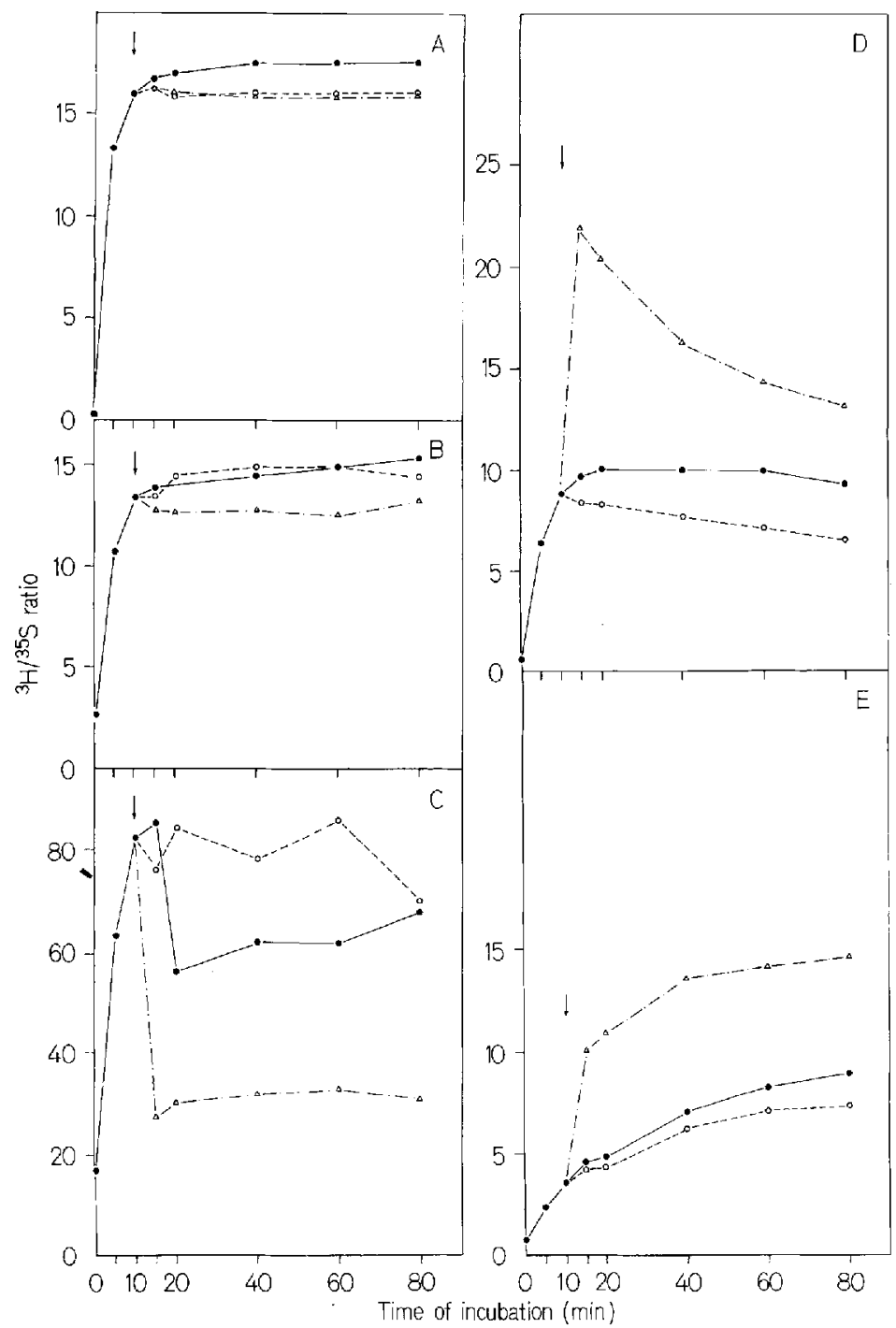

Fig. 1. Incorporation of $\left[{ }^{3}\right.$ HJleucine into various fractions of a cell-free homogenate. A cell-free homogenate was prepared from ${ }^{35} \mathrm{~S}$-labelled Neurospora hyphae. $\left[{ }^{3} \mathrm{H}\right]$ Leucine was incorporated after addition of chloramphenicol. To aliquots of the incubation mixture, cycloheximide or puromycin were added after 10 min of incubation. Samples were withdrawn at the times indicated and subfractionated by differential centrifugation. ${ }^{3} \mathrm{H}$ and ${ }^{35} \mathrm{~S}$ radioactivities were determined in the protein of the various fractions and their ratios plotted against time of incubation. (- Control; $(\mathrm{O}-\mathrm{O}$ ) cycloheximide; $(\Delta---\Delta)$ puromycin. (A) Homogenate; (B) free ribosome fraction; (C) microsomal fraction; (D) cytosol fraction; (E) mitochondrial fraction. Arrows indicate time of addition of cycloheximide and puromycin

cells and isolated mitochondria it was calculated, that mitochondria occupy about $23 \%$ of total cellular protein in Neurospora [7].

Table 1 indicates that even after 80 min of incubation a considerable amount of the labelled polypeptide chains are still associated with the free and microsomal ribosomes (about $40 \%$ ). The data, however, clearly indicate that a relatively large amount of the protein material rcleased from the ribosomes is associated with the mitochondrial fraction, viz. about $10 \%$.

From the above data we conclude that the ${ }^{3} \mathrm{H}-$ labelled proteins of the mitochondria must be of cytoplasmic origin since mitochondrial translation was effectively inhibited. The amounts of polypeptide material tranferred to the mitochondria in the system in vitro in relation to total proteins synthesized are comparable to the amounts transferred in whole cells. The relative preferential distribution of ${ }^{3} \mathrm{H}$ label in membrane-bound ribosomes suggests that these ribosomes have a higher synthetic capacity than the free ribosomes in our system.

The retention of much of the nascent ${ }^{3} \mathrm{H}$ label by the ribosomes suggests that our system in vitro represents a limited read-out system. This conclusion is further corroborated by the use of initiation inhibitors such as aurintricarboxylic acid [8]. This antibiotic in concentrations up to $0.1 \mathrm{mM}$ had no effect on incorporation. 
Table 1. Distribution of ${ }^{35} \mathrm{~S}$ and ${ }^{3} \mathrm{H}$ radioactivities among the various cell fractions after incorporation of ${ }^{3} \mathrm{H} / \mathrm{leucine}$ into a cell-free homogenate from ${ }^{35} S$-labelled Neurospora cells

A cell-free homogenate was labelled as outlined for Fig. $1{ }^{35} \mathrm{~S}$ and ${ }^{3} \mathrm{H}$ radioactivities were determined after 10 and 80 min incorporation. The table also contains the distribution of ${ }^{3} \mathrm{H}$ radioactivity after puromycin inhibition. Puromycin was added after 10 min incorporation and samples werc withdrawn 5 and 70 min later. The radioactivities are related to $0.5 \mathrm{ml}$ homogenate corresponding to $0.25 \mathrm{~g}$ cells wet weight

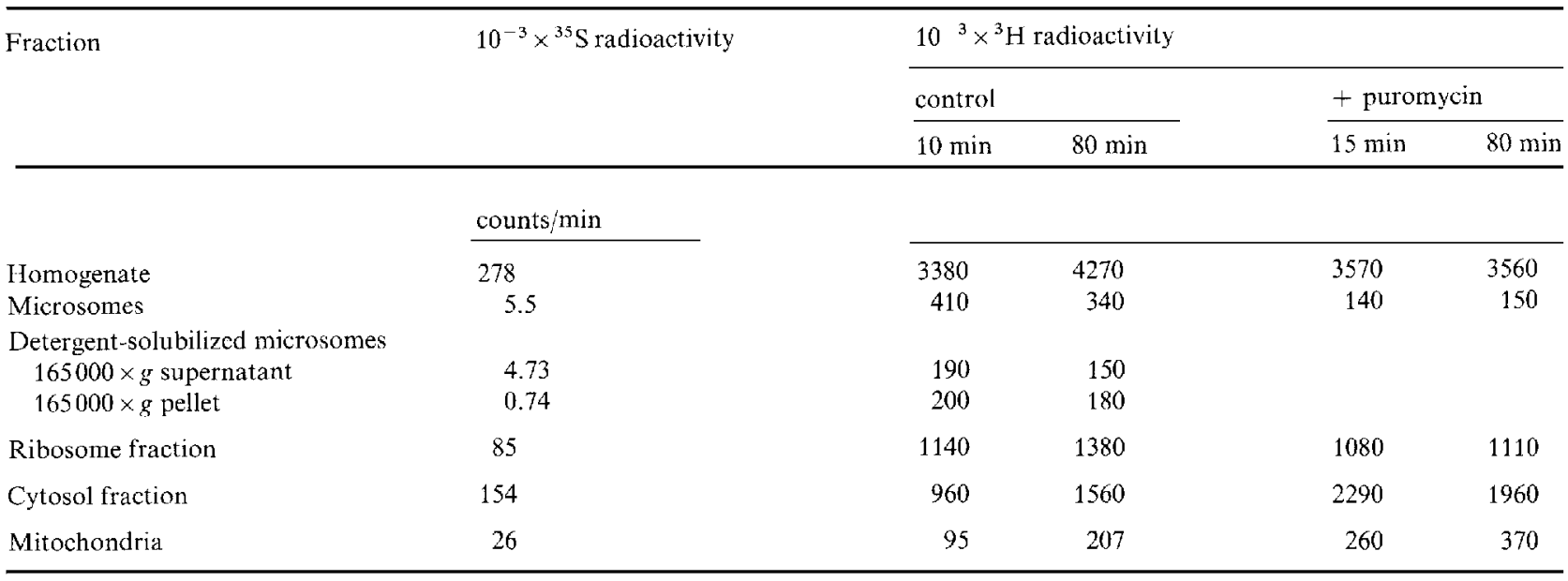

The Effect of Cycloheximide and Puromycin on Import of Polypeptides by Mitochondria

A homogenate as described above was allowed to incorporate $\left[{ }^{3} \mathrm{H}\right]$ leucine for $10 \mathrm{~min}$ after which time cycloheximide was added in a concentration which completely inhibited cytoplasmic translation. The inhibitory effect of the cycloheximide is clearly shown in Fig. 1 where the increase in the ${ }^{3} \mathrm{H} /{ }^{35} \mathrm{~S}$ ratio of the homogenate was immediately halted. The microsome and ribosome fractions showed little change in the ${ }^{3} \mathrm{H} /{ }^{35} \mathrm{~S}$ ratio. The cytosol however, showed a decline in the ${ }^{3} \mathrm{H} /{ }^{35} \mathrm{~S}$ ratio. A salient feature of this experiment is that as shown, the mitochondrial fraction continued to accumulate label at a rate similar to the control.

These results indicate that the movement of labelled polypeptides into mitochondria is independent of protein synthesis by either the cytoplasmic or the mitochondrial translation system, at least on a shortterm basis. The data further suggest that an extramitochondrial pool of proteins could be located in the cytosol. The decrease in ${ }^{3} \mathrm{H}$ radioactivity shown by the cytosol in the presence of cycloheximide is accompanied by a commensurate increase in ${ }^{3} \mathrm{H}$ radioactivity in the mitochondria.

Translation was also arrested when puromycin was added after $10 \mathrm{~min}$ incorporation. The rise in ${ }^{3} \mathrm{H}^{\beta 3} \mathrm{~S}$ ratio was immediately halted. The microsome fraction showed a sharp drop in ${ }^{3} \mathrm{H} /{ }^{35} \mathrm{~S}$ ratio within $5 \mathrm{~min}$ indicating release of nascent chains from ribosomes. There was no clear evidence of vectorial insertion of the chains into microsomal vesicles. This is in sharp contrast to the observations with endoplasmic reticulum fraction from rat liver, where practically no peptidyl-puromycin chains were recover- ed in the incubation medium [9]. The nascent chains of the free ribosomes were not released, a fact for which no explanation is evident. It should be pointed out that also in bacterial and reticulocyte cell-free systems $[10,11]$ and in systems with isolated rough endoplasmic reticulum [9] puromycin was never found to effect complete release of nascent polypeptide chains. In most cases the released chains comprised some $30-60 \%$ of total nascent chains.

The rapid release of ${ }^{3} \mathrm{H}$ label from the microsomes was accompanied by a similar increase in the cytosol during the first $5 \mathrm{~min}$ of puromycin treatment. The latter increase was followed by a slow decrease which persisted for the whole duration of the experiment. The mitochondria showed an increase in ${ }^{3} \mathrm{H}$-labelled protein after puromycin treatment. This increase continued even when the decrease in the microsomes and the increase in the cytosol was finished. The absolute changes in the ${ }^{3} \mathrm{H}$-radioactivity of the cell fractions are listed in Table 1.

The continued uptake of polypeptides by mitochondria in the presence of puromycin, lends further support to the view that extramitochondrial pools of mitochondrial proteins exist. The kinetics and extent of release of nascent chains from the microsomes are compatible with a release of proteins destined for the mitochondria into the cytosol.

\section{Immunological Identification of Proteins Imported into the Mitochondria}

The appearance of specific proteins in the mitochondria of a cell-free homogenate was followed by immunoprecipitation from solubilized mitochondria. 


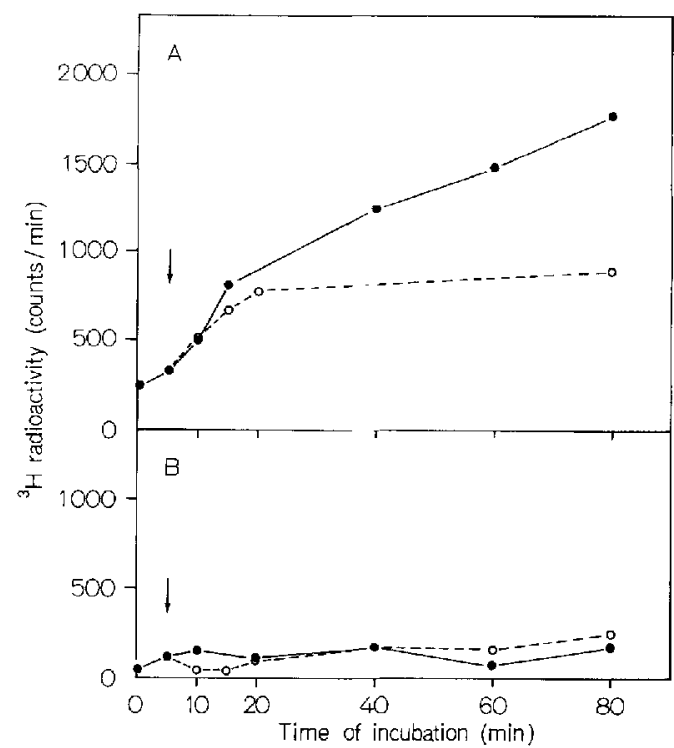

Fig.2. Immunoprecipitation of mitochondrial matrix proteins from the mitochondrial fraction after incorporation of $\left.{ }^{3} \mathrm{H}\right]$ leucine into a cell-free homogenate in the presence and absence of cycloheximide. Mitochondria were lysed in Triton X-100 and divided into two equal portions. To one portion antibodies against mitochondrial matrix proteins were added, to the other portion bovine serum albumin and antibodies against this protein. ${ }^{3} \mathrm{H}$ radioactivities were determined in the immunoprecipitates. (A) Antibodies against mitochondrial matrix proteins; $(B)$ bovine serum albumin and antibodies against bovine serum albumin. Arrows indicate time of addition of cycloheximide. (-C) Control; $\left(0_{---0}^{-}\right.$plus cycloheximide

The appearance of ${ }^{3} \mathrm{H}$-labelled matrix proteins with increasing time of incorporation is shown in Fig. 2 and 3. There was a distinct lag of $5-10 \mathrm{~min}$ before the appearance of ${ }^{3} \mathrm{H}$-labelled matrix proteins, followed by a sustained increase for the duration of the experiment. The final ${ }^{3} \mathrm{H} /{ }^{35} \mathrm{~S}$ ratio of the immunoprecipitated matrix was $25-30 \%$ that of the whole mitochondria, suggesting a lower rate of transfer for matrix proteins than for the overall average mitochondrial protein.

The effect of cycloheximide on the transfer of matrix proteins is shown in Fig. $2 \mathrm{~A}$. When cycloheximide was added $5 \mathrm{~min}$ after the start of leucine incorporation, the transfer of ${ }^{3} \mathrm{H}$-labelled matrix protein continued.

Fig. $3 \mathrm{~A}$ shows the effect of puromycin on the labelling of matrix proteins in the mitochondria. The puromycin was added after $10 \mathrm{~min}$ of incorporation. The transfer of matrix proteins continues in the presence of puromycin. However, the final ${ }^{3} \mathrm{H} /{ }^{35} \mathrm{~S}$ ratio is lower than that found in control mitochondria. It is possible that the peptidyl puromycin chains are not as readily recognized by the antibody as are the completed chains, or that part of the peptidyl puro-

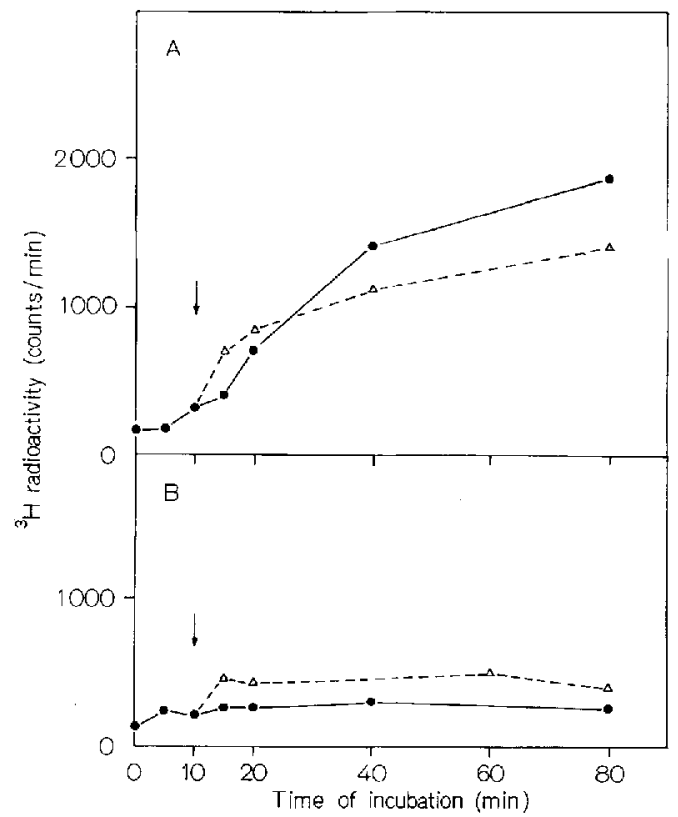

Fig. 3. Immunoprecipitation of mitachondrial matrix proteins from the mitochondrial fraction after incorporation of ${ }^{3}$ H]leucine into a cell-free homogenate in the presence and absence of puromycin. Mitochondria were lysed in Triton X-100 and divided into two equal portions. To one portion antibodies against mitochondrial matrix proteins were added, to the other portion unlabelled cytoplasmic ribosomes from Neurospora and antibodies against cytoplasmic ribosomes. The ${ }^{3} \mathrm{H}$ radioactivities in the immunoprecipitates were determined. (A) Antibodies against mitochondrial matrix proteins; (B) cytoplasmic ribosomes and antibodies against cytoplasmic ribosomes. Arrows indicate time of addition of puromycin.

(- Control; $\left(\Delta^{-} \Delta\right)$ plus puromycin

mycin chains are unspecifically attached to the mitochondria.

The nature of the immunoprecipitated matrix proteins was investigated by subjecting the immunoprecipitates to dodecylsulfate gel electrophoresis. There was not exact coincidence between the ${ }^{35} \mathrm{~S}$ and ${ }^{3} \mathrm{H}$ radioactivity peaks, but the patterns obtained match those obtained in vivo after short periods of labelling [1,2].

The pattern of increase of ${ }^{3} \mathrm{H} /{ }^{35} \mathrm{~S}$ ratio in carboxyatractyloside binding protein appearing in mitochondria is shown in Fig. 4. The increase starts without a lag and the ${ }^{3} \mathrm{H} /{ }^{35} \mathrm{~S}$ ratio at the end of the incubation period is considerably higher than that of matrix proteins.

Fig. 5 shows the radioactivity profiles of the immunoprecipitated carboxyatractyloside-binding protein in a gel electrophoretogram. The ${ }^{35} \mathrm{~S}$ radioactivity shows a major peak with an apparent molecular weight of 32000 . A distinct peak with an apparent molecular weight of about 60000 can also be seen, which probably represents the dimeric form of the carboxyatractyloside-binding protein. Furthermore, in the molecular weight range of $10000-30000$ a considerable amount 


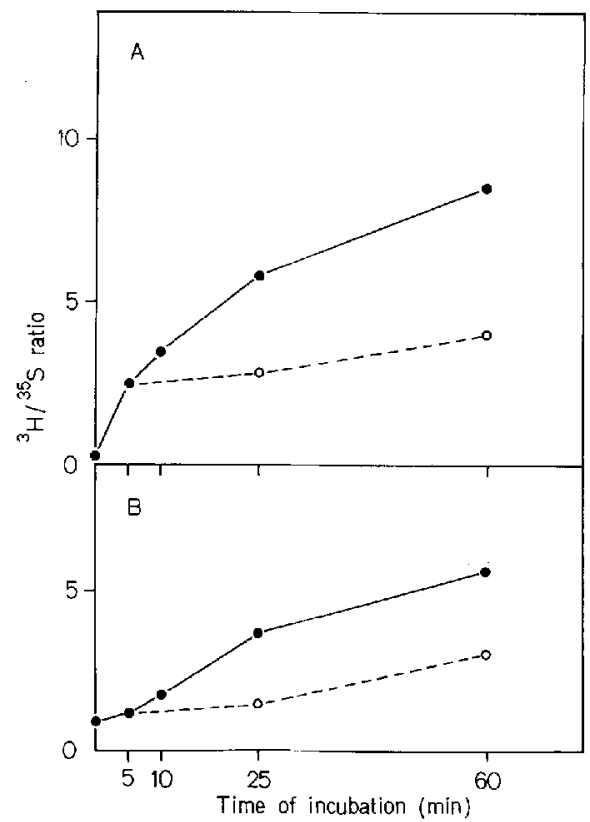

Fig. 4. Immunoprecipitation of carboxyatractyloside-binding protein from the mitochondrial fraction after incorporation of $\left[{ }^{3} H\right] l e u c i n e$ in a cell-free homogenate in the presence and absence of cycloheximide. Mitochondria from a cell-free homogenate labelled as outlined for Fig. 2 were dissolved in Triton X-100 and carboxyatractylosidebinding protein was immunoprecipitated. The immunoprecipitates were analysed by gel electrophoresis in the presence of dodecylsulfate. ${ }^{3} \mathrm{H}$ and ${ }^{35} \mathrm{~S}$ radioactivities were determined in the total immunoprecipitates and in the electrophoretic peak fractions (apparent molecular weight 32000). (A) Total immunoprecipitate; (B) gel electrophoretic peak fraction. (@- C Control; $\left(\mathrm{O}_{---O}\right)$ cycloheximide added after $5 \mathrm{~min}$ of incorporation

of ${ }^{35} \mathrm{~S}$ radioactivity is present, which corresponds to proteolytic degradation products of the carboxyatractyloside-binding protein. This degradation is observed only after incubation of mitochondria in vitro and is an expression of the exceptional lability of this protein $[1,12]$. There is coincidence between the major ${ }^{3} \mathrm{H}$ radioactivity peak and the monomeric carboxyatractyloside-binding protein. Additional ${ }^{3} \mathrm{H}$-labelled peaks of higher and lower molecular weights can also clearly be seen. The higher molecular weight material can be attributed partly to the dimeric carboxyatractyloside binding protein, the lower molecular weight components to breakdown of newly formed carboxyatractyloside-binding protein.

In Fig. $4 \mathrm{~B}$ the ${ }^{3} \mathrm{H} /{ }^{\beta 5} \mathrm{~S}$ ratios of the electrophoretic fractions corresponding to the monomeric carboxyatractyloside-binding protein are shown. The ratios are lower than those of the total immunoprecipitates and in this case a lag period was observed.

Gel electrophoretic analysis of immunoprecipitated cytochrome $c$ is shown in Fig. $6 \mathrm{~A}$. The ${ }^{25} \mathrm{~S}$ peak representing preexistent cytochrome $c$ and the ${ }^{3} \mathrm{H}$

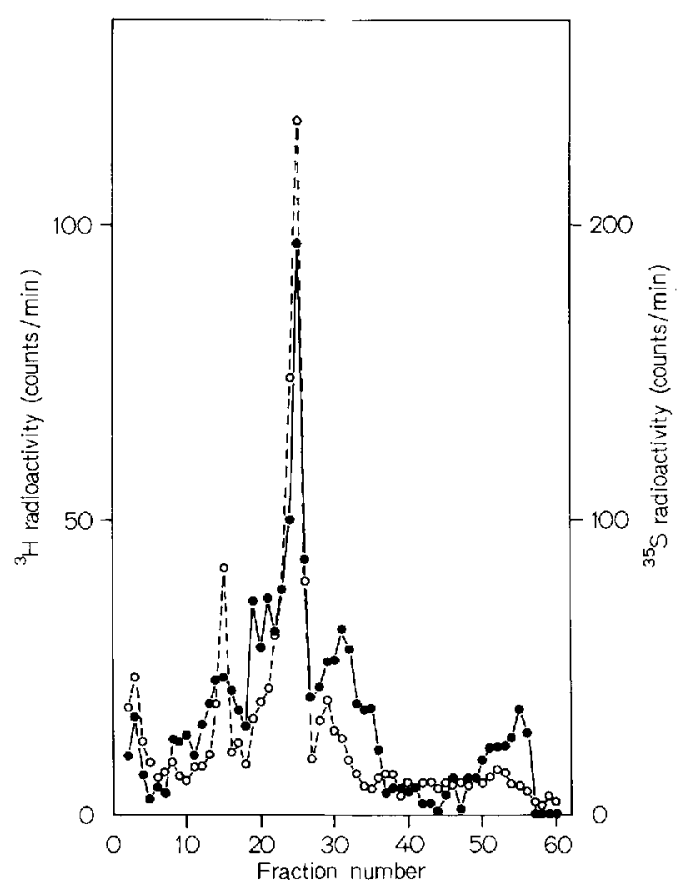

Fig. 5. Gel electrophoretic analysis in the presence of dodecylsulfate of immunoprecipitated carboxyatractyloside-binding protein. Carboxyatractyloside-binding protein was immunoprecipitated from mitochondria derived from a ${ }^{35} \mathrm{~S}$ prelabelled cell-free homogenate which was incubated with $\left[{ }^{3} \mathrm{H}\right] \mathrm{leucine}$ for $20 \mathrm{~min}$. (-) ${ }^{3} \mathrm{H}$; $(\mathrm{O}-\mathrm{O})^{35} \mathrm{~S}$

radioactivity incorporated in vitro showed exact coincidence. It appears therefore that cytochrome $c$ (or apo-cytochrome $c$ ) is synthesized in vitro and translocated into the mitochondria. The ${ }^{3} \mathrm{H} /{ }^{35} \mathrm{~S}$ ratio of the cytochrome $c$ peak is very close to that of total mitochondrial protein suggesting that cytochrome $c$ is transferred more efficiently than matrix proteins.

The independence of cytochrome $c$ transport from synthesis is shown in Fig. 6B. In the presence of puromycin the ${ }^{3} \mathrm{H} /{ }^{35} \mathrm{~S}$ ratio of cytochrome $c$ continued to increase despite the fact that translation was effectively inhibited.

\section{Specificity of Transfer}

of Cytoplasmically Translated Proteins

into Mitochondria

Transfer of defined mitochondrial proteins into the mitochondria in vitro has been demonstrated. Nevertheless, non-specific association of cytosolic proteins as a source of apparent transfer has not been ruled out. A series of experiments was therefore designed to test the specificity of protein transfer into mitochondria.

A dual-labelled homogenate was sampled after $10 \mathrm{~min}$ and again after $80 \mathrm{~min}$ incubation and the electrophoretic protein patterns of mitochondria and cytosol compared. It can be seen in Fig. 7 that mito- 


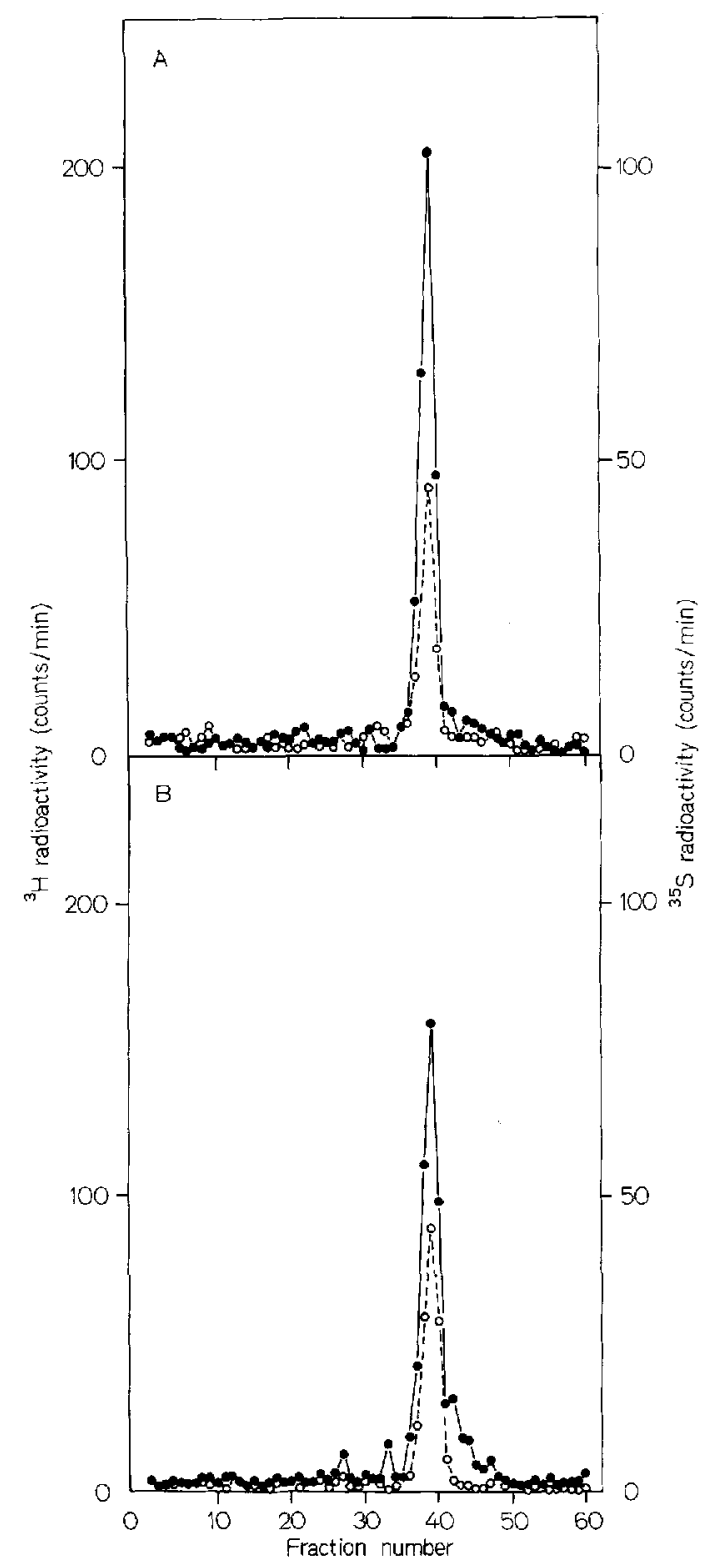

Fig. 6. Gel electrophoretic analysis in the presence of dodecylsulfate of immunoprecipitated cytochrome c. A cell-free homogenate was prepared from ${ }^{35} \mathrm{~S}$-labelled cells and incubated with $\left[{ }^{3} \mathrm{H}\right]$ leucine. After $10 \mathrm{~min}$ incubation, the mixture was halved. One portion was further incubated for $70 \mathrm{~min}$, to the other portion puromycin was added and incubation continued for $70 \mathrm{~min}$. In mitochondria prepared after $10 \mathrm{~min}$ of incubation the ${ }^{3} \mathrm{H} /{ }^{35} \mathrm{~S}$ ratio of the immunoprecipitated cytochrome $c$ was 2.05 , as compared to 4.70 in the control sample and 3.76 in the puromycin-treated sample. (A) Control $80 \mathrm{~min}$; (B) puromycin after $10 \mathrm{~min}$ and further incubation for $70 \mathrm{~min}$. (- ${ }^{3} \mathrm{H} ;(\mathrm{O}-\mathrm{O})^{35} \mathrm{~S}$

chondria and cytosol differ clearly in their ${ }^{35} \mathrm{~S}$ radioactivity patterns. Also, the ${ }^{3} \mathrm{H}$ radioactivity patterns of mitochondria and cytosol are quite different. This leads us to conclude that the proteins synthesized in vitro which are associated with the mitochondria do not represent unspecifically attached cytosolic pro- teins. However, as much overlap exists between the protein patterns of cytosol and mitochondria this experiment cannot be said to unequivocally demonstrate that only specific transfer of mitochondrial proteins takes place. The ${ }^{3} \mathrm{H}$ and ${ }^{35} \mathrm{~S}$ radioactivity patterns of mitochondria are not identical, although there is considerable similarity at least after $80 \mathrm{~min}$ of incorporation. The reason for this may be that mitochondrial tanslation was blocked in the cell-free homogenate, that different proteins may be synthesized in vitro at a different rate than in vivo, that different proteins may be transferred with different efficiencies, and that modification of proteins in vitro may not take place in the same way as in vivo.

Non-specific adsorption of cytosol proteins to mitochondria was further assayed by the following procedure. Cytosol and mitochondrial fractions were isolated from dual-labelled homogenate. To the lysed mitochondria was added unlabelled cytosol and antibodies against cytosol proteins. Antibodies against cytosol proteins were also added to the labelled cytosol. The antibodies precipitated $25 \%$ of the total ${ }^{3} \mathrm{H}$ and $13 \%$ of the total ${ }^{35} \mathrm{~S}$ radioactivity from the cytosol. These percentages did not change between 5 and $80 \mathrm{~min}$ of incorporation of $\left[{ }^{3} \mathrm{H}\right]$ leucine into the homogenate. In the case of the mitochondria the antibodies against the cytosol proteins precipitated $0.5 \%$ $1 \%$ of the ${ }^{3} \mathrm{H}$ and $2.5 \%$ of the ${ }^{35} \mathrm{~S}$ radioactivity. These values are relatively high and may reflect the presence of contaminating mitochondrial proteins in the cytosol preparations used to raise the antibodies. It can be seen however, that non-specific attachment of cytosolic proteins could not be responsible for the presence of the majority of cytoplasmically translated proteins in the mitochondria.

The role of non-specific precipitation in the immunoprecipitation experiments was also investigated. To aliquots of solubilized mitochondria from a homogenate, bovine serum albumin and antibodies against this protein were added. ${ }^{3} \mathrm{H}$ and ${ }^{35} \mathrm{~S}$ radioactivities in the immunoprecipitate were less than $0.5 \%$ of those in the total mitochondria (Fig.2B). In a further experiment, cytoplasmic ribosomes and antibodies against these ribosomes were added to the solubilized mitochondria. In this instance the ${ }^{3} \mathrm{H}$ radioactivity precipitated was higher than in the immunoprecipitates of bovine serum albumin. However, this radioactivity did not increase with time of incubation as it does in mitochondria and in immunoprecipitated matrix proteins (Fig. 3B). It appears therefore that proteins of cytoplasmic ribosomes synthesized in vitro do not become unspecifically attached to the mitochondria. The relatively high and time-independent basic level of co-precipitated ${ }^{3} \mathrm{H}$ radioactivity may be explained by the observation that in experiments in vitro, proteins become associated with ribosomes and microsomes in a non-specific manner [13]. 


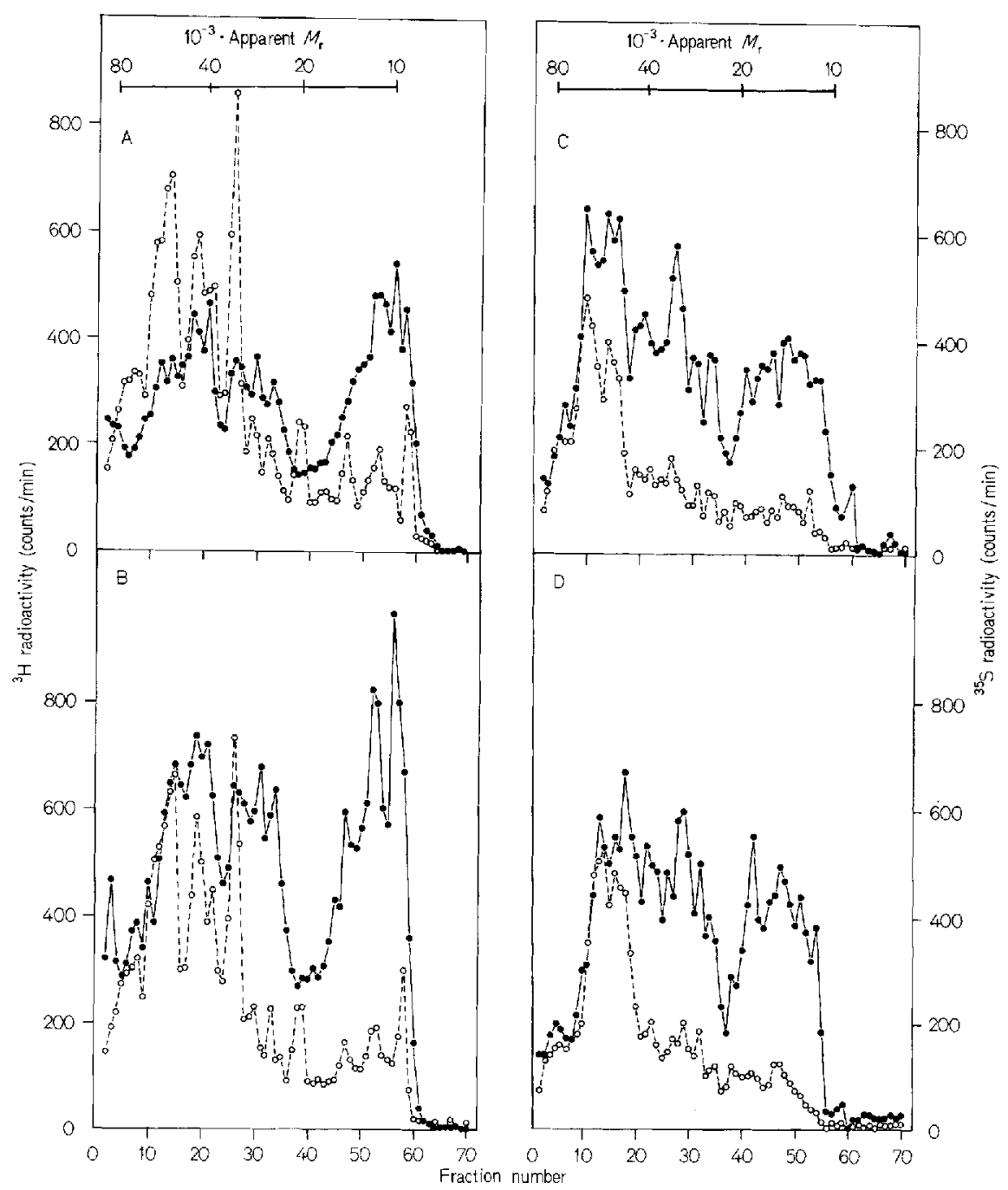

Fig. 7. Gel electrophoretic analysis in the presence of dodecylsulfate of ${ }^{3} \mathrm{H}$-labelled proteins in the mitochondrial and cytosolic fraction after incorporation of ${ }^{3} \mathrm{H}$ ]leucine into a cell-free homogenate. A cell-free homogenate was prepared from ${ }^{35} \mathrm{~S}$-labelled hyphae and incubated with $\left[{ }^{3} \mathrm{H}\right]$ leucine in the presence of chloramphenicol. Samples were withdrawn after 10 and $80 \mathrm{~min}$. Mitochondria and cytosol were prepared, dissolved in dodecylsulfate-containing buffer, dialysed against the same buffer and subjected to gel electrophoresis in the presence of dodecylsulfate. (A, B) Mitochondria: (C, D) cytosol. (A, C) 10-min incubation; (B, D) 80-min incubation. (-.- ${ }^{3} \mathrm{H}$; (O-—O) ${ }^{35} \mathrm{~S}$

Selective transfer of newly synthesized proteins was further investigated in the following experiment. Matrix proteins were isolated from cells labelled with $\left[{ }^{3} \mathrm{H}\right]$ leucine and also from unlabelled whole cells. A cell-free homogenate was prepared from cells prelabelled with ${ }^{35} \mathrm{~S}$. To aliquots of this cell-free homogenate were added: (a) unlabelled matrix proteins and $\left[{ }^{3} \mathrm{H}\right]$ leucine; (b) matrix proteins labelled with $\left[{ }^{3} \mathrm{H}\right]-$ leucine. Both homogenates were then incubated at $25^{\circ} \mathrm{C}$ and samples withdrawn and fractionated at the times indicated in Fig. 8 . In homogenate a the ${ }^{3} \mathrm{H}$ radioactivity in protein increased during the incubation in accordance with the results presented in Fig. 1, whereas the ${ }^{3} \mathrm{H}$ radioactivity remained constant in homogenate $\mathrm{b}$ (see Fig. $8 \mathrm{~A}$ ). The total ${ }^{3} \mathrm{H}$ radioactivity in homogenate $\mathrm{b}$ was approximately $5-10 \%$ of the final ${ }^{3} \mathrm{H}$ radioactivity in homogenate a. If it is assumed that the relative proportions of proteins synthesized in vitro and in vivo are the same then the amounts of ${ }^{3} \mathrm{H}$ radioactivity in matrix proteins are quite similar in the two homogenates.

The distribution of label between the cell fractions is presented in Fig. $8 \mathrm{~B}, \mathrm{C}$ and D. Of the total $\left[{ }^{3} \mathrm{H}\right]-$ leucine incorporated in vitro $30 \%$ was recovered in the cytosol while $60 \%$ of the labelled matrix proteins which were added in homogenate $b$ was found in the cytosol. The ribosome plus microsome fraction carried the bulk of the $\left[{ }^{3} \mathrm{H}\right]$ leucine incorporated in vitro. It is noteworthy that of the pre-labelled matrix added some $20 \%$ was recovered from this fraction. This finding highlights the problems raised by non-specific binding of polypeptides to ribosomes and microsomes. Analysis of the mitochondrial fraction showed that a substantial amount of protein synthesized in vitro 

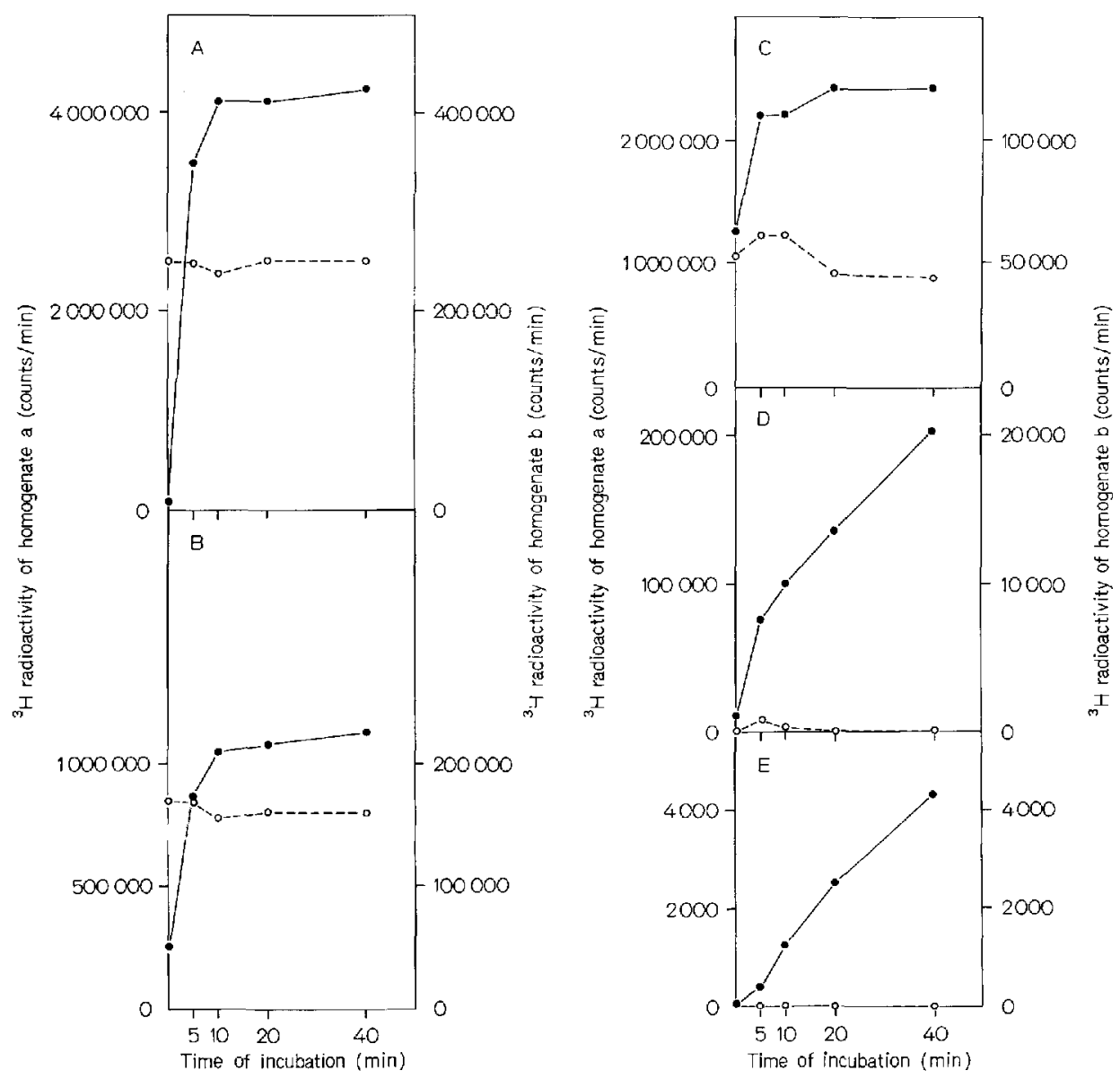

Fig. 8. Incubation of a cell-free homogenate with matrix proteins prepared from mitochondria homogeneously labelled with $\left.{ }^{3} \mathrm{H}\right]$ leucine in vivo. A cell-free homogenate from ${ }^{35} \mathrm{~S}$-labelled cells was divided into two equal portions. To one portion (homogenate a), a matrix protein fraction from unlabelled mitochondria was added and then incubation with $\left[{ }^{3} \mathrm{H}\right]$ leucine was carried out as described for Fig. 1 . To the other portion (homogenate b), a matrix protein fraction from ${ }^{3} \mathrm{H}$-prelabelled mitochondria was added and incubation was carried out without added $\left[{ }^{3} \mathrm{H}\right]$ leucine in parallel to the first portion. Samples were withdrawn at the times indicated and fractionated as outlined before. ${ }^{3} \mathrm{H}$ radioactivities in protein were determined. (A) Homogenate; (B) cytosol; (C) ribosomes and microsomes; (D) mitochondria; (E) matrix proteins immunoprecipitated from mitochondria. (-) Homogenate plus unlabelled matrix and $\left[{ }^{3} \mathrm{H}\right]$ leucine, homogenatc a; $(\mathrm{O}---\mathrm{O})$ homogenate plus ${ }^{3} \mathrm{H}$-labelled matrix and unlabelled leucine, homogenate $b$

was associated with the mitochondria. Furthermore, this label was unaffected by the addition of unlabelled matrix proteins. The mitochondria isolated from the homogenate containing pre-labelled matrix proteins did not take up any significant amount of ${ }^{3} \mathrm{H}$-labelled protein.

Immunoprecipitation of matrix proteins from homogenates $a$ and $b$ showed that matrix proteins synthesized in vitro were recovered in the mitochondria from homogenate a, but no ${ }^{3} \mathrm{H}$-labelled matrix proteins were recovered from mitochondria isolated from homogenate incubated in the presence of pre-labelled matrix proteins.

The mitochondria can clearly differentiate betweeen preexistent and newly synthesized matrix proteins. The ability of the mitochondria to recognize the newly synthesized matrix proteins may lie in the structure and/or conformation of these proteins. The antibodies recognize both the newly synthesized and preexistent proteins, thus, a large measure of similarity exists between the newly synthesized matrix proteins and the finished products in the mitochondria. It is significant that pre-labelled matrix proteins did not compete with the newly synthesized proteins for uptake by the mitochondria. The absence of prelabelled matrix proteins from the mitochondria can be taken as proof that the import of protein into the mitochondria is a specific process and is not due to nonspecific association of proteins with the mitochondria.

\section{DISCUSSION}

The results presented above show that in a cell-free homogenate, synthesis of mitochondrial proteins takes 
place on cytoplasmic ribosomes. The data furthermore show that these proteins are subsequently transported into the mitochondria. As observed in experiments on whole cells, the synthesis and the transport are separated in time. The uptake of the proteins by the mitochondria appears to be a specific process whereby only mitochondrial proteins are imported. The efficiency of transfer of these proteins is quite high as approximatcly $10-15 \%$ of the total labelled translation products released from the ribosomes are taken up. This efficiency is reflected in the specific labelling of the mitochondrial proteins which is close to that of the cytosolic proteins.

The immunoprecipitation data show clearly that defined mitochondrial proteins are transported. However in the case of matrix proteins, the final specific labelling of the transported proteins was considerably lower than that of total mitochondrial protein. We may conclude from this that in this case the transfer process is working at a reduced efficiency in the system in vitro.

Although transport of mitochondrial proteins has been demonstrated it cannot be inferred from the experiments described above that the proteins are in fact transported to and integrated into their functional sites. The small quantities of protein synthesized in vitro make it difficult to demonstrate integration of the transported material into functional sites. However, some positive indication that proteins are integrated can be shown by results obtained in vitro with synthesis of cytochrome oxidase subunits [14]. Incubation of a cell-free homogenate with $\left[{ }^{3} \mathrm{H}\right]-$ leucine in the absence of chloramphenicol yielded an immunoprecipitate from mitochondria with an antibody to complete cytochrome oxidase which contained ${ }^{3} \mathrm{H}$-labelled subunits of cytoplasmic origin. A further observation was that a cytosol fraction from Neurospora cells stimulated the integration of mitochondrially synthesized subunits of cytochrome oxidase into an immunoprecipitable complex $[14,15]$. Preincubation of whole cells with cycloheximide yielded a cytosol which could no longer stimulate the integration of the mitochondrially made subunits. It was suggested from this finding that the cytosol contained a pool of cytochrome oxidase precursors which were necessary for the assembly of cytochrome oxidase. When a cytosol fraction from cells pulse-labelled with $\left[{ }^{14} \mathrm{C}\right]$ leucine was incubated with isolated mitochondria, ${ }^{14} \mathrm{C}$-labelled subunits 6 and 7 were found in the immunoprecipitated whole enzyme. These observations may be taken as an indication that cytosol proteins can be taken up by mitochondria and assembled into functional locations.

The mechanism by which these proteins are transferred from the cytosol into the mitochondria cannot be clearly defined at this stage. The results obtained in the present study are in agreement with the findings reported from experiments in vivo [1]. They support the view that mitochondrial proteins are released from cytoplasmic ribosomes into an extramitochondrial pool. It is difficult to reconcile our findings with the direct insertion mechanism as suggested for mitochondrial proteins in yeast $[3-6]$. Electronmicroscopic examination of mitochondrial fractions fixed with glutaraldehyde in the presence of $\mathrm{Mg}^{2+}$ failed to reveal cytoplasmic ribosomes bound to the mitochondrial membranes. This holds for mitochondrial preparations from the cell-free homogenate as well as for mitochondrial preparations obtained under the conditions described by Kellems et al. for yeast mitochondria [6]. Absence of mitochondria-bound ribosomes and contamination of mitochondria by rough endoplasmic reticulum has been reported for rat liver $[16,17]$.

The data we have presented indicate that the cytosol is the site of the extramitochondrial pool. No evidence of localisation of mitochondrial proteins in microsomal vesicles was found. On the other hand, results presented indicate that mitochondrial proteins may be synthesized on membrane-bound polysomes with subsequent release into the cytosol. The release of polypeptides into the cytosol is clearly opposite to the situation described with endoplasmic reticulum of exocrine tissues [18]. On the other hand, occurrence of membrane-bound ribosomes in non-exocrine tissues has been described [19]. Release of nascent chains from preparations of membrane-bound ribosomes by puromycin into the medium and not into the interior of the vesicles was reported [20]

Several studies have been made on the sites of synthesis of mitochondrial proteins. A number of studies were focussed on cytochrome $c$, but the results of different groups are at variance. Free and membrane-bound polysomes have been invoked by different authors for the synthesis of cytochrome $c$ [21-24].

Immunological studies on the synthesis of mitochondrial glutamate dehydrogenase [13] and of mitochondrial and cytoplasmic isoenzymes of malate dehydrogenase $[25,26]$ in liver led to the proposal that the synthesis of these enzymes took place on membrane-bound ribosomes. It was further suggested that the microsomal vesicles contained these proteins in an enzymatically active form. It was not shown however that the newly synthesized enzyme was present only in the microsomal fraction and not in the free ribosome fraction. In view of the reported unspecific association of mitochondrial glutamate dehydrogenase with microsomes [13], a definite exclusion of redistribution artifacts appears to be necessary before safe conclusions on the sites of synthesis can be drawn.

It has been suggested that cytoplasmic ribosomes which were recovered from the mitochondrial fraction 
of rat liver were the site of synthesis of mitochondrial proteins [27]. This suggestion was made on the basis of experiments in which iodinated antibodies against total mitochondrial protein were reacted with different classes of cytoplasmic polysomes. The nature of the membranes in the mitochondrial fraction to which these cytoplasmic ribosomes were bound has however not been determined.

Very recently, Shore and Tata have made a different approach to investigate the site of synthesis of mitoplast proteins in rat liver $[16,17]$. They translated poly(A)-RNA from free cytoplasmic ribosomes and from rough endoplasmic reticulum in a cell-free system from wheat embryo. The translation products in vitro were analysed with antibodies to total mitoplast proteins. Both free and membrane-bound ribosomes were found to synthesize mitochondrial proteins. The majority of the immunologically detectable proteins was reported to be coded by poly(A)-R NA associated with bound ribosomes (about $75 \%$ ). The endoplasmic reticulum fraction was separated into two fractions on the basis of their sedimentation velocities. The poly(A)-RNA from the slowly sedimenting rough endoplasmic reticulum was found to code for mitoplast proteins to a higher extent than the RNA from rapidly sedimenting endoplasmic reticulum.

The form in which mitochondrial proteins are transported from the cytoplasmic site of synthesis to the mitochondria remains to be determined. An energy-dependent process which involved a phospholipid binding was suggested for transport of proteins into the mitochondria of rat liver $[28,29]$. Confirmation of this view has not been forthcoming. Also with rat liver, a study was made on the import of purified mitochondrial aspartate aminotransferase into isolated mitochondria [30]. The authors suggest that completed enzymatically active protein molecules can be imported. The results we have presented on matrix proteins are in disagreement with such a view as isolated matrix proteins were not imported into mitochondria. On the contrary the mitochondria selectively imported newly formed matrix proteins, suggesting some mechanism of selective recognition by the mitochondria. We are tempted to speculate that cytoplasmically translated mitochondrial proteins may have some signal which enables them to recognize the mitochondrial membranes. Such a recognition signal could be contained in the conformation of the protein. Another possibility is that the proteins are synthesized as precursors which have additional sequences such as shown for a number of secretory proteins $[31,32]$. It was suggested that these additional sequences serve as signals to aid the vectorial discharge of nascent peptides across the endoplasmic reticulum membrane $[32,33]$. In this context the recent work of Dobberstein et al. [34] appears to be of interest. These authors have shown that the small subunit of ribulosebisphosphate carboxylase is translated in a wheat germ extract as a precursor with a molecular weight of 20000 as compared to 16500 for the functional subunit. This protein is synthesized on cytoplasmic ribosomes and transported into the chloroplasts where it becomes associated with the large subunit which is synthesized on chloroplast ribosomes [35]. The authors speculate that the additional sequence plays a role in the transport into the chloroplasts.

Further experiments will have to clarify a number of questions which are relevant in connection with a transfer from the cytosol compartment into the mitochondria. One major question concerns the permeability of the outer mitochondrial membrane. A number of studies would indicate that the outer membrane is impermeable for substances with molecular weights higher than $5000-10000[36,37]$. A direct approach to test the permeability for proteins has been made with cytochrome $c[38,39]$. The isolated outer membrane of rat lier was found to be impermeable for this protein. However, before the impermeability of the outer mitochondrial membrane for proteins may be taken as a fact, some more detailed studies appear to be necessary to prove that this observation in vitro actually reflects the situation in vivo.

M. A. Harmey wishes to thank Ciba-Geigy for a visiting fellowship. The authors acknowledge the skilful assistance of Dictlinde Rose and Heide Rothe. This work was supported by the Deutsche Forschungsgemeinschaft, Schwerpunktprogramm 'Biochemie der Morphogenese'.

\section{REFERENCES}

1. Hallermayer, G., Zimmermann, R. \& Neupert, W. (1977) Eur. f. Biochem. 81, 523-532.

2. Harmey, M. A., Hallermayer, G. \& Neupert, W. (1976) in Genetics and Biogenesis of Chloroplasts and Mitochondria (Bücher, Th. et al., cds) pp. 813-818, North-Holland, Amsterdam.

3. Kellems, R. E. \& Butow, R. A. (1972) J. Biol. Chem. 247, $8043-8050$

4. Kellems, R. E., Allison, V. F. \& Butow, R. A. (1974) J. Biol. Chem. 249, 3297-3303.

5. Kellems, R. E.\& Butow, R. A. (1974) J. Biol. Chem. 249, $3304-$ 3310.

6. Kellems, R. E., Allison, V. F. \& Butow, R. A. (1975) J. Cell Biol. 65, 1- 14.

7. Weiss, H., Jagow, G. v., Klingenberg, M. \& Bücher, Th. (1970) Eur. J. Biochem. 14, 75-82.

8. Grollmann, A. P. \& Stewart, M. L. (1968) Proc. Natl Acad. Sci, U.S.A. 61, 719-725.

9. Redman, C. M. \& Sabatini, D. D. (1966) Proc. Natl Acad. Sci. U.S.A. $56,608-615$.

10. Takanami, M. \& Yan, Y. (1965) Proc. Natl Acad. Sci. U.S.A. $54,1450-1458$.

11. Morris, A., Arlinghaus, R., Favelukes, S. \& Schweet, R. (1963) (1963) Biochemistry, 2, 1084-1090.

12. Klingenberg, M., Aquila, H., Riccio, P., Buchanan, B. B., Eiermann, W. \& Hackenberg, H. (1975) in Electron Transfer 
Chains and Oxidative Phosphorylation (Quagliariello, E. et al., eds) pp. $431-438$, North-Holland, Amsterdam.

13. Godinot, C. \& Lardy, H. A. (1973) Biochemistry, 12, 20512060

14. Rücker, A. v. (1976) Ph.D. Thesis, University of Munich, Germany.

15. Rücker, A. v., Neupert, W. \& Werner, S. (1976) in Genetics, Bingenesis and Bioenergetics of Mitochondria (Bandlow, W. et al., eds) pp. 259-267, Walter de Gruyter, Berlin and New York.

16. Shore, G. C. \& Tata, J. R. (1977) J. Cell Biol. 72, 714-725.

17. Shore, G. C. \& Tata, J. R. (1977) J. Cell Biol. 72, 726-743.

18. Sabatini, D. D. \& Kreibich, G. (1976) in The Enzymes of Biological Membranes (Martonosi, A., ed.) vol. 2, pp. 531-579, John Wiley \& Sons, London, New York.

19. Tata, J. R. (1971) Sub-Cell. Biochem. 1, 83-89.

20. Andrews, T. M. \& Tata, J. R. (1971) Biochem. I. 121, 683-694.

21. Gonzalez-Cadavid, N. F. (1974) Sub-Cell. Biochem. 3, $275-$ 309.

22. Kadenbach, B. (1970) Eur. J. Biochem. 12, 392- 398.

23. Gonzalez-Cadavid, N. F. \& Saez de Cordova, C. (1974) Biochem. J. 140,157-167.

24. Davidian, N. M. \& Penniall, R. (1971) Biochem. Biophys. Res. Commun. 44, 15-21.

25. Bingham, R. W. \& Campbell, P. N. (1972) Biochem. J. 126, $211-215$.
26. Dölken, G., Brdiczka, D. \& Pette, D. (1973) FEBS Lett. 35, $247-249$.

27. Gaitskhoki, V. S., Kisselev, O. I., Klimov, N. A., Monakhov, N. K., Mukha, G. V., Schwartzman, A. L. \& Neifakh, S. A. (1974) FEBS Lett. 43, 151-154.

28. Kadenbach, B. (1967) Biochim. Biophys. Acta, 134, 430-442.

29. Kadenbach, B. (1967) Biochim. Biophys. Acta, 138, 651-654.

30. Marra, E., Doonan, S., Saccone, C. \& Quagliariello, E. (1977) Biochem. J. 164, 685-691.

31. Milstein, C., Brownlee, G. G., Harrison, T. M. \& Mathews, M. B. (1972) Nat. New Biol. 239, 117-120.

32. Blobel, G. \& Dobberstein, B. (1975) J. Cell Biol. 67, 835-851.

33. Blobel, G. \& Dobberstein, B. (1975) J. Cell Biol. 67, 852-862.

34. Dobberstein, B., Blobel, G. \& Chua, N.-H. (1977) Proc. Natl Acad. Sci. U.S.A. 74, 1082-1085.

35. Blair, G. E. \& Ellis, R. J. (1973) Biochim. Biophys. Acta, 3/9, $223-234$.

36. O'Brien, R. L. \& Brierley, G. (1965) J. Biol. Chem. 240, 45274531.

37. Pfaff, E., Klingenberg, M., Ritt, E. \& Vogell, W. (1968) Eur. $J$. Biochem. 5, 222-232.

38. Wojtczak, L. \& Zaluska, H. (1969) Biochim. Biophys. Acta, $193,64-72$.

39. Wojtczak, L. \& Sottocasa, G. L. (1972) J. Membrane Biol. 7, $313-324$.

M. A. Harmey, Department of Botany, University College Dublin, Belfield, Stillorgan Road, Dublin, Ireland

G. Hallermayer, H. Korb, and W. Neupert*, Institut für Physiologische Chemie,

Physikalische Biochemie und Zellbiologie der Ludwig-Maximilians-Universität München,

Goethestraße 33, D-8000 München 2, Federal Republic of Germany

* To whom correspondence should be addressed. 